\title{
Assessment of the Relationship between ESR Signal Intensity and Grain Size Distribution in Shear Zones within the Atotsugawa Fault System, Central Japan
}

\author{
Emilia B. Fantong1 ${ }^{*}$, Akira Takeuchi' ${ }^{1}$, Toshio Kamishima', Ryosuke Doke ${ }^{2}$ \\ ${ }^{1}$ Graduate School of Science and Engineering, University of Toyama, Toyama, Japan \\ ${ }^{2}$ Hot Spring Research Institutes of Kanagawa Prefecture, Kanagawa, Japan \\ Email: ${ }^{*}$ yebifa@gmail.com, ${ }^{*}$ abiyetoh@yahoo.com
}

Received 30 July 2014; revised 25 August 2014; accepted 21 September 2014

Copyright (C) 2014 by authors and Scientific Research Publishing Inc.

This work is licensed under the Creative Commons Attribution International License (CC BY). http://creativecommons.org/licenses/by/4.0/

c) (i) Open Access

\section{Abstract}

For the first time, a relationship between ESR signal intensity and grain size distribution (sieve technique) in shear zones within the Atotsugawa fault system have been investigated using fault core rocks. The grain size distributions were estimated using the sieve technique and microscopic observations. Stacks of sieves with openings that decrease consecutively in the order of $4.75 \mathbf{~ m m}$, $1.18 \mathrm{~mm}, 600 \mu \mathrm{m}, 300 \mu \mathrm{m}, 150 \mu \mathrm{m}$ and $75 \mu \mathrm{m}$ were chosen for this study. Grain size distributions analysis revealed that samples further from the slip plane have larger $d_{50}$ (average gain size) $(0.45$ $\mathbf{m m}$ at a distance of $30-50 \mathrm{~mm}$ from the slip plane) while those close to the slip plane have smaller $d_{50}$ values $(0.19 \mathrm{~mm}$ at a distance of $0-10 \mathrm{~mm}$ from the slip plane). This is due to intensive crushing that is always associated with large displacement during fault activities. However, this pattern was not respected in all shear zones in that, larger $d_{50}$ values were instead observed in samples close to the slip plane due to admixture of fault rocks from different fault activities. Results from ESR analysis revealed that the relatively finer samples close to the slip plane have low ESR signals intensity while those further away (coarser) have relatively higher signal intensity. This tendency however, is not consistence in some of the shear zones due to a complex network of anatomizing faults. The variation in grain size distribution within some of the shear zones implies that, a series of fault events have taken place in the past thus underscoring the need for further investigation of the possibility of reoccurrence of faults.

${ }^{*}$ Corresponding author.

How to cite this paper: Fantong, E.B., Takeuchi, A., Kamishima, T. and Doke, R. (2014) Assessment of the Relationship between ESR Signal Intensity and Grain Size Distribution in Shear Zones within the Atotsugawa Fault System, Central Japan. International Journal of Geosciences, 5, 1282-1299. http://dx.doi.org/10.4236/ijg.2014.511106 


\section{Keywords}

\section{Active Fault, Shear Zones, ESR Signal Intensity, Grain Size Distribution, Atotsugawa Fault System}

\section{Introduction}

Shear zones are zones of strong deformation that consist of volumes of intensely fractured rocks and may vary in thickness from sub-millimeters to kilometers [1]. Based on the degree of deformation, shear zones can be divided into two main parts: a fault core zone [2] and a damage zone [3]. A fault core zone is a zone where most of the displacement is accommodated [4] while damage zone is the network of related secondary structures [5]. Both zones within an active fault constitute significant sources of information to the seismogenic and deformation behavior of faults. The deformation in a shear zone causes developments of characteristic fabrics and deformation history in the shear zone [6], which can give more clarification on geodynamics of the faults. Moreover, seismogenic behavior of a fault depends greatly on the internal structure of fault zone and constitutive properties of fault rocks e.g., [7] [8]. Although there are many studies on shear zone descriptions and deformational mechanisms e.g., [9]-[16], only few e.g. [17]-[22] have so far related the description of cataclastic rocks (fault gouge) to electron spin resonance (ESR) method, which is based on the detection of paramagnetic defects in minerals produced by natural radiation that has accumulated for a long time and produces a characteristic signal detectable with an ESR spectrometer. By measuring the intensity of these trapped electrons, the rate of comminution and/or displacement of a fault can be clarified or envisaged. Because decrease in signal intensity is as a result of large displacement, which will cause comminution and a reduction in grain size, [10] [23]-[26] reported that, grain size analysis is an important prerequisite for the characterization of fault rocks.

In central Japan, the activities of the active Atotsugawa fault system have been investigated in different shear zones using different methods. For example, [20] [27] have dated the Atotsugawa fault with the ESR method using defect centers in quartz grains extracted from a fault zone consisting of intra-fault gouge zone and a brecciated zone. [28] has equally dated the Ushikubi fault (a member of the Atotsugawa fault system) with the ESR method using defect centers in calcareous fault gouge that was collected from shear zones. [29] has also unraveled the geometry and the movement history of the Ushikubi fault by investigating a complicated network of faulting within the Ushikubi shear zone. However, none of the above studies clearly investigate how grain size distributions (especially sieve technique), rate of deformation (displacement) vary with proximity to a slip plane.

Accordingly, this study has the following objectives:

1) Assess the relationship between ESR signal intensity and grain size distribution (sieve analysis and microscopic observation) with proximity to a slip plane.

2) Assess the relationship between the rate of deformation (displacement) with proximity to a slip plane in the Atotsugawa fault system (the Ushikubi and the Atotsugawa fault) in central Japan.

\subsection{Tectonic Setting of the Study area}

The Atotsugawa fault system, which is in the Northern margin of the Hida Highland lies within a complex tectonic zone consisting of the Pacific plate, the Philippine Sea plate, the Amurian plate and the Okhotsk plates [30]. This system consists of the Ushikubi fault, the Atotsugawa fault and the Mozumi-Sukenobe fault (Figure 1). Both the Ushikubi, and Atotsugawa faults are NE-SW dextral trending strike slip structure which belong to the Atotsugawa fault system and are $52 \mathrm{~km}$ and $64 \mathrm{~km}$ long, respectively [31]. Due to the complex nature of this zone, central Japan is vulnerable to fault activities, thus underscoring the importance of investigating the objectives of this study.

\subsection{Sample Localities and Description}

Samples were collected from shear zones along the Ushikubi and the Atotsugawa faults. Once the shear zones were identified, the width of the entire shear zone and fault core zones were measured. Then slip planes in the fault core zone were identified, and their strike and dips measured. Then the shear zone was cleaned up to expose fresh surfaces, photographs were taken, and samples were collected. Samples intended for thin sections 


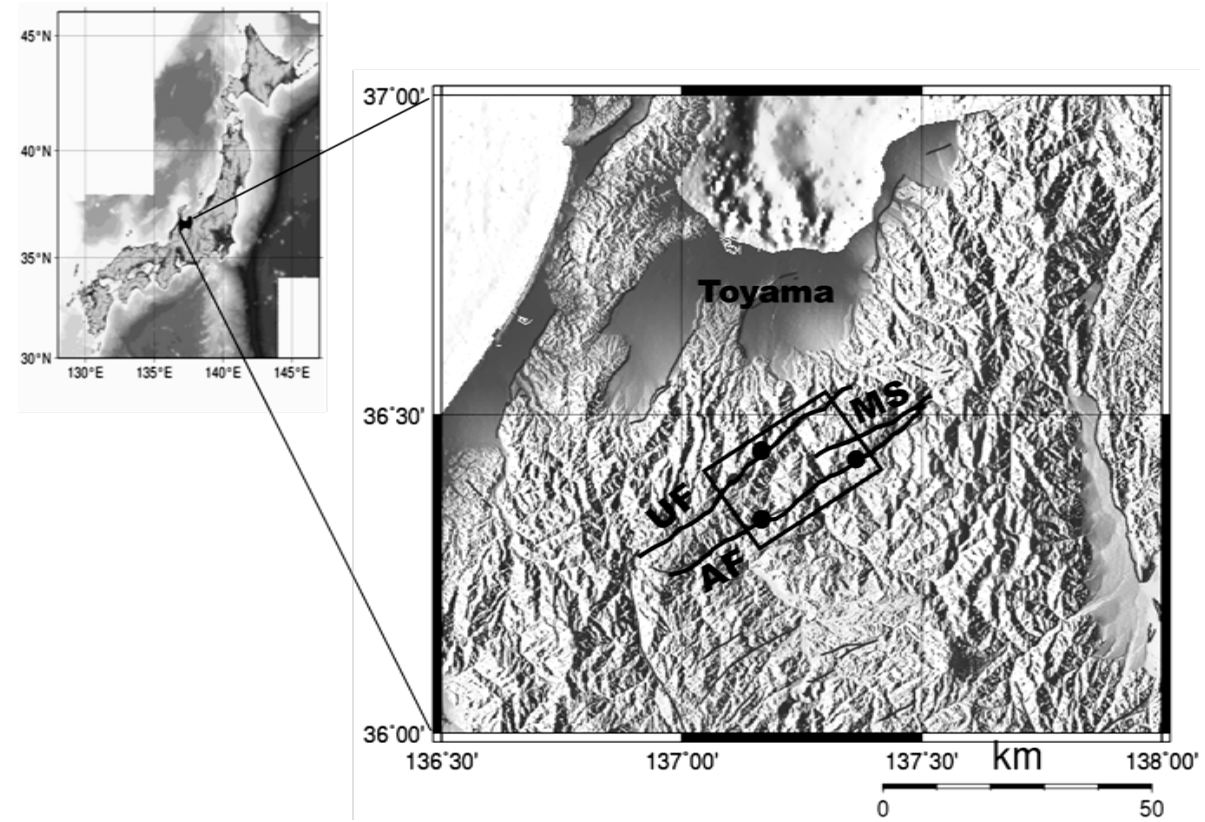

Figure 1. Index map indicating the different faults within the Atotsugawa fault system and sample sites. UF: Ushikubi fault; MS: Mozumi-Sukenobe fault; AF: Atotsugawa fault.

preparation were collected undisturbed while noting their orientations. Loose samples were collected at random without taking note of their orientations. All these samples were collected either vertically or laterally with proximity to a slip plane depending on the position of the identified slip plane. However, detail sampling procedures have been discussed elsewhere.

\subsubsection{The Ushikubi Fault}

Three shear zones along the western part of the Ushikubi fault were investigated.

1) Shirakimine shear zone one (SZ I)

Exposures of shear zone one (SZ I) in the study area show that it is made up of alternating layers of gneiss and crystalline limestone that have been crushed to form breccias, cataclasites and fault gouge represented in Figure 2 by A, B, C, D, E and G. The entire shear zone is $12 \mathrm{~m}$ wide and range in color from grayish, brownish to whitish, thus mesocratic in terms of color. This shear zone comprises a main fault (MF) and two secondary faults with strike and dip as indicated on the stereonet of Figure 2(c). In this shear zone only a fault core zone is visible.

\section{2) Shirakimine shear zone two (SZ II)}

This shear zone is $3.7 \mathrm{~m}$ wide and consists of a complicated network of faults with different orientations as indicated in Figure 3(a). In this shear zone, both the fault core and the damage zones are exposed. The protolith is gneiss, which has been crushed to form breccias, gouge and cataclasites of various types (e.g. mega breccia, protocataclasites) Figure 3(b). Calcite veins are also a common feature in both the crushed and the partially damage rocks. The different fault orientations are represented on the stereonet of Figure 3(c).

3) Shirakimine shear zone (SZ III)

The exposed part of this shear zone is $1.2 \mathrm{~m}$ wide and is made up of two sub faults F1 and F2 in Figure 4. The entire shear zone can be divided into two main zones; the damage and fault core zones. The gouge zone around F2 is $150 \mathrm{~mm}$ thick and is made up of alternating layers of whitish, grayish and dark gouges (Figure 4(b)).The damage zone consists of crystalline limestones and gneisses that have been partly crushed to form megabreccias (e.g. Figure 4(c)). The damaged zone is characterized with fractures of varying orientations which have been filled with dark incohesive gouges. 

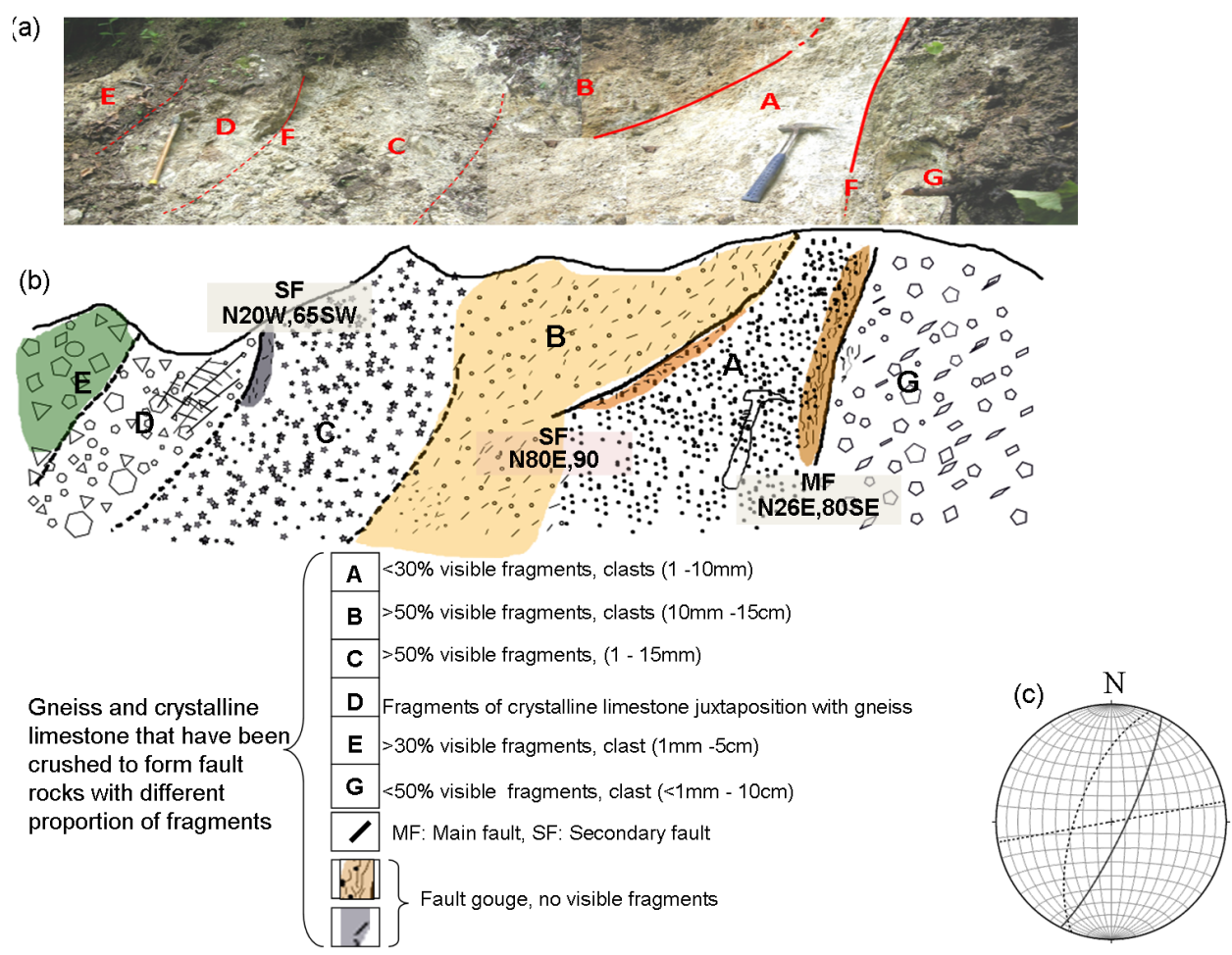

Figure 2. Exposure of shear zone one (SZ I) along the central part of the Ushikubi fault. (a) Photograph of the exposed outcrop showing different fault rock boundary in red dotted lines, SF: Secondary fault and MF: Main fault in red solid lines; (b) A sketch of the outcrop with detail description of the fault rock; (c) Lower-hemisphere, equal-area stereographic projection of fault orientations.

(a)
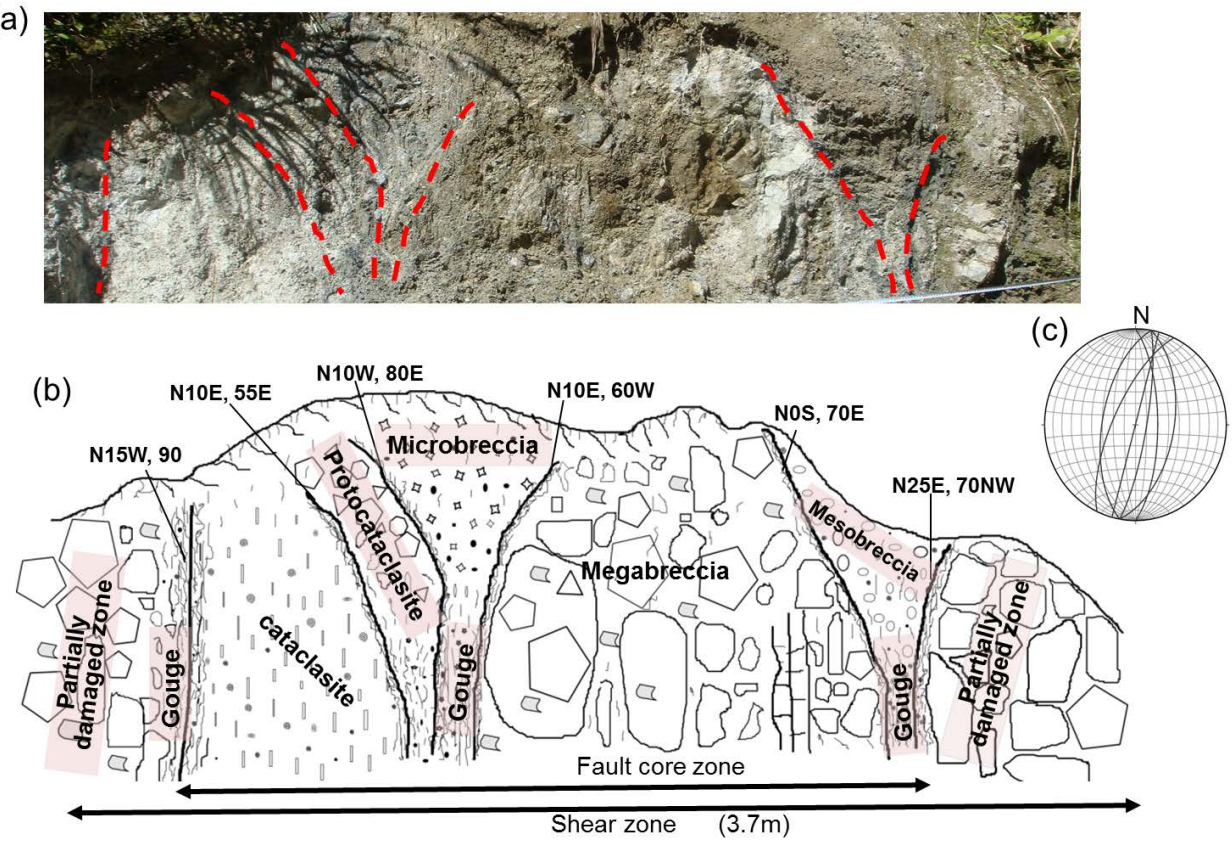

c)

Figure 3. Exposure of shear zone two (SZ II) along the central part of the Ushikubi fault. (a) Photograph of the exposed outcrop showing anastomosing network of faulting in red dotted lines; (b) A sketch of the outcrop with detail description of the fault rock; (c) Lower-hemisphere, equalarea stereographic projection of fault orientations. 


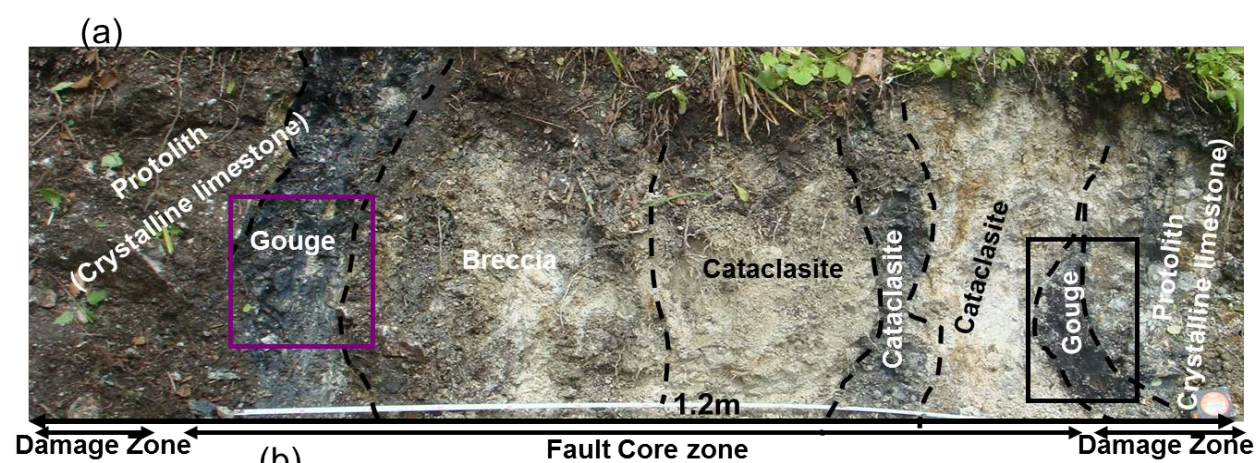

(b)

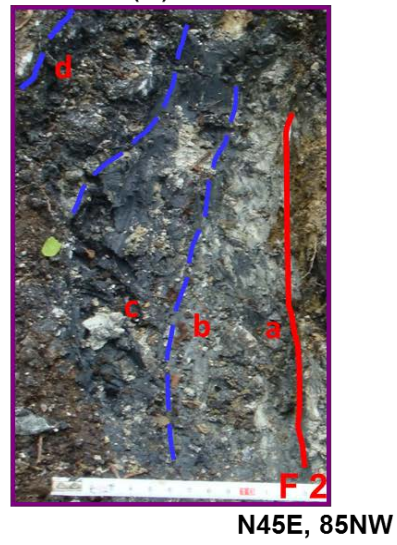

(c)

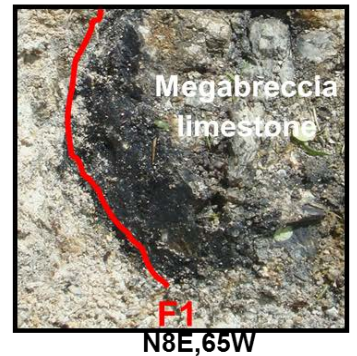

Figure 4. Exposure of shear zone three (SZ III) along the central part of the Ushikubi fault. (a) Photograph of the exposed outcrop showing different fault rock in black dotted lines. Both the damage and the fault core zone are exposed in this shear zone; (b) A close up photograph of the gouge zone showing a fault plane in red solid line; (c) A close up photograph showing a fault plane in red solid line and a megabreccia of limestone.

The SaSZ is located along the eastern part of the Atotsugawa fault (Figure 5). This shear zone is exposed in an area made up of the Tetori group (alternating layers of sandstone and mudstone) which has been crushed to form breccias, cataclasites and fault gouge (Figure 5). A slip plane striking N35E and dipping 25W is also present. Both the damage and the fault core zones are exposed in this shear zone. The gouge within the fault core zone has a range of colors (whitish, grayish, brownish, dark) reflecting the initial nature of the protolith.

2) Suganuma shear zone (SuSZ)

The SuSZ is located along the central part of the Atotsugawa fault and has a slip plane striking N40E and dipping 74W (Figure 6). It consists of a damaged and a fault core zone made up of gneiss which has been crushed to form breccia, cataclasites and gouge (Figure 6).

\section{Analytical Procedures}

All analyses were carried out in the department of earth science at the University of Toyama, Japan.

\subsection{Sieve Analysis}

Sieve analysis was done in order to see how grain size varies among shear zones and with proximity to a slip plane.

Sieves with openings that decrease consecutively in the order of $4.75 \mathrm{~mm}, 1.18 \mathrm{~mm}, 600 \mu \mathrm{m}, 300 \mu \mathrm{m}, 150$ $\mu \mathrm{m}$ and $75 \mu \mathrm{m}$ were chosen for this purpose. Disaggregated samples were put in stack of sieves with a pan and cover. Sieving was done manually for each sample for 5 - 10 minutes. However, sieving time was longer for finer particles. Separated particles were then weighed using an electronic balance (Chyo MG Balance Corporation, Kyoto, Japan) with a sensitivity of $10 \mathrm{mg}$. Care was taken as to make sure sieves remained clean throughout the process. For example particles that were stuck in the openings were poke out using a brush. Because of 


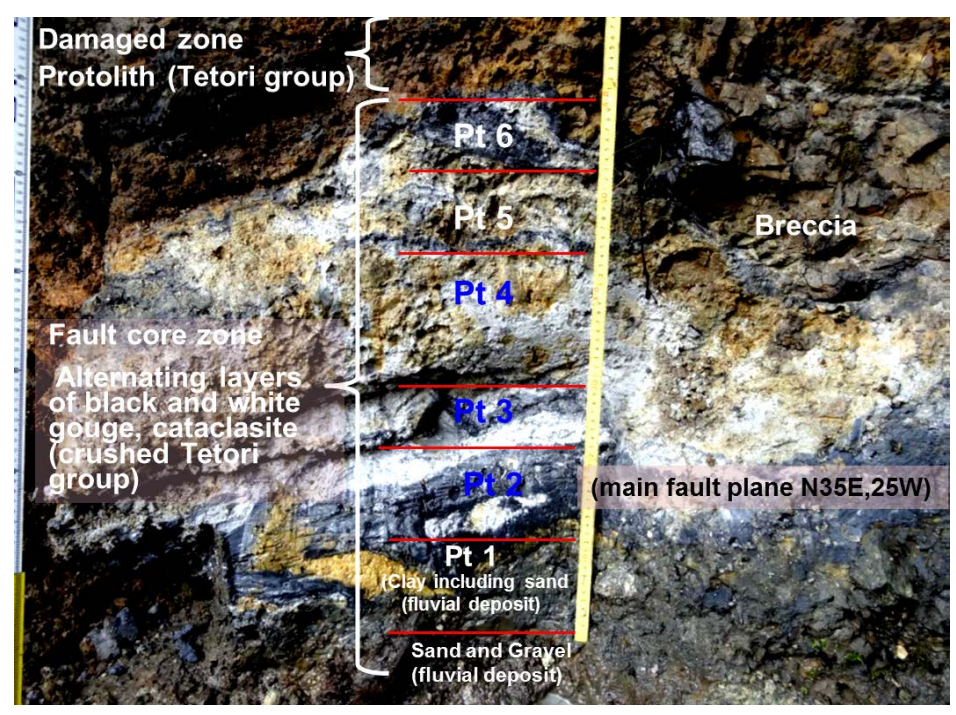

Figure 5. Exposure of shear zone at Sako (SaSZ) along the eastern part of the Atotsugawa fault showing different fault rock and sampling points from 1 - 6. Only part of the damage and fault core zones are visible.

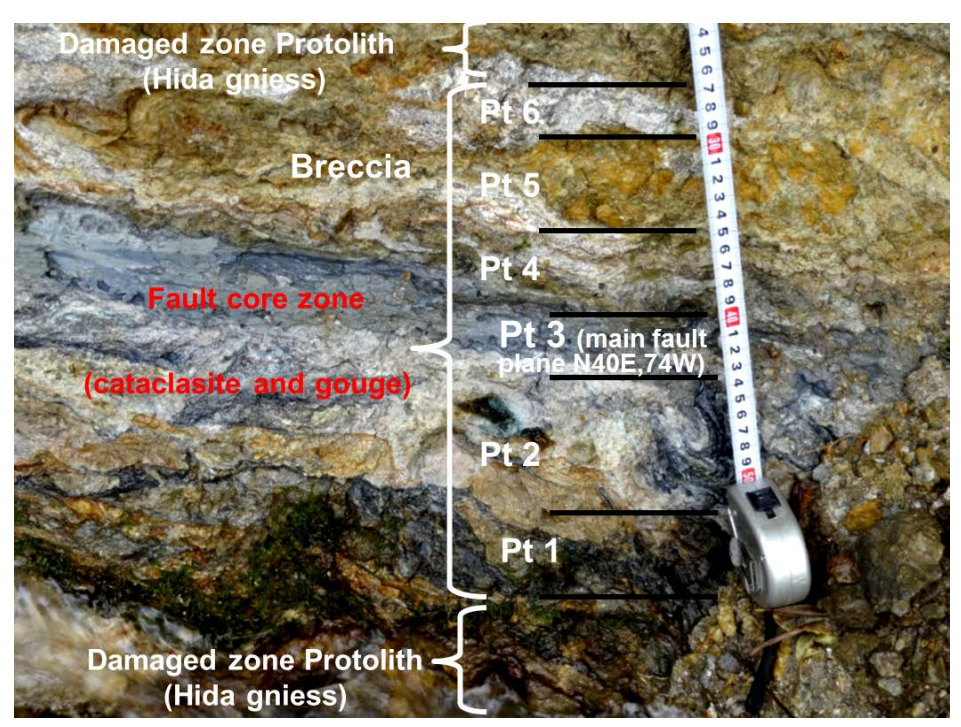

Figure 6. Exposure of shear zone at Suganuma (SuSZ) along the eastern part of the Atotsugawa fault showing different fault rock and sample points from $1-6$. Both the damage and the fault core zone are exposed in this shear zone.

the difficulties involved in taking samples within a narrow range in a fault core zone, the weight of the samples used in this study may not be representative of the entire shear zone. However, the total weight of the samples in each shear zone was harmonized to ease the comparison of their distribution curves. During sieving, note was taken of the initial and final weight and the mass of the particles retained on each sieve. A percentage of total weight retained and cumulative weight was then calculated using Equation (1). From there values of cumulative percent of total weight retained and the percentage of passing of finer grains were obtained.

$$
\text { Weight of sample retained on each sieve/Total weight } \times 100
$$

\subsection{ESR Analysis}

Laboratory analysis involved the use of a JEOL JES-REIX ESR spectrometer operating at an X-band frequency. 
Prior to this experiment, the samples were dried under dark conditions to avoid possible effects of sunlight because it can affect the intensity of ESR signals [32] and portion suspected of containing impurities (e.g., soil, roots) were carefully scratched and removed with a knife to avoid contamination. The less contaminated portions were then gently disheveled using a steel mortar and pistil and, then sieved for homogeneity to obtain size fractions ranging from $63->250 \mu \mathrm{m}$. No chemical treatment was performed on the samples because the purpose of this experiment is to see how signal intensity varies in fault gouge collected at different points from a slip plane. Other experimental conditions that were maintained throughout the whole experiment were; center field: $334 \mathrm{mT}$, field modulation: $0.4 \times 0.1-2 \times 0.01 \mathrm{mT}$, receiver gain: $5 \times 100-10 \times 100$, time constant: 0.3 1sec, sweep width: 4 - $7.5 \mathrm{mT}$, sweep field time: 10 secs, and sweep time of 8 minutes. However, the conditions used for the analysis varied in samples in the different shear zones but were respected within the same shear zones for comparison with spectra of the same species. For fault gouge samples in which quartz was dominant, the intensity of the radiation induced signals were calibrated using a manganese marker. For those that contain a higher concentration of calcite, natural manganese were equally of higher concentration and thus the intensity of the radiation induced signals were calibrated using the natural manganese peaks within signals of same species. The ESR intensities of the signals were generally calibrated using the average intensity of the $3^{\text {rd }}$ and the $4^{\text {th }}$ $\mathrm{Mn}^{2+}$ lines as reported in [28].

\subsection{XRD Analysis}

X-ray diffraction (XRD) patterns that are used in this study were measured with a MiniFlex II diffractometer target; $\mathrm{Cu}$, voltage; $30 \mathrm{Kv}$, current; $15 \mathrm{~mA}$, scan speed $4.000^{\circ} / \mathrm{min}$, measurement angle $3^{\circ}$ - $60^{\circ}$.

\subsection{Microscopic Investigation}

Photomicrographs from thin sections used in this study were taken using a super probe JEOL JXA-8230T Electron probe microanalyzer and an OPTIPHOT 2-POL optical microscope with a camera head; DS-5 m and DS-L1 control unit.

\section{Results and Interpretations}

\subsection{Grain Size Distribution of Fault Rocks}

\subsubsection{Sieve Analysis}

Figures 7(a)-(c) shows cumulative curves obtained from samples collected from shear zones along the Ushikubi and the Atotsugawa faults. Average grain sizes $\left(d_{50}\right)$ of those curves indicate that most of the samples showed an increasing trend in the grain size distribution away from the slip plane. For example within the Ushikubi fault (e.g., SZ III), the $\mathrm{d}_{50}$ values varies as follows: $0.19 \mathrm{~mm}$ (point "a" at $0-10 \mathrm{~mm}$ ), $0.22 \mathrm{~mm}$ (point "b" at $10-20$ $\mathrm{mm}$ ), $0.35 \mathrm{~mm}$ (point "c" at $20-30 \mathrm{~mm}$ ) and $0.45 \mathrm{~mm}$ (point "d" at $30-50 \mathrm{~mm}$ ) from the slip plane (Figure 7(a)). While in the Atotsugawa fault (e.g., SaSZ), the $d_{50}$ values varies as follows $0.58 \mathrm{~mm}$ (point 6 at $37.5 \mathrm{~cm}$ ), $0.55 \mathrm{~mm}$ (point 5 at $31 \mathrm{~cm}$ ), $0.54 \mathrm{~mm}$ (point 4 at $19 \mathrm{~cm}$ ), $0.49 \mathrm{~mm}$ (point 3 at $9 \mathrm{~cm}$ ), $0.46 \mathrm{~mm}$ (point 2 at slip plane), $0.49 \mathrm{~mm}$ (point 1 at $12 \mathrm{~cm}$ ) from the slip plane (Figure 7(b)). Samples further from the slip plane had larger $d_{50}$ values whereas those close to the slip plane had smaller $d_{50}$ values. Although this trend is evident in most of the shear zones, some did not respect this trend in that larger $\mathrm{d}_{50}$ values $(0.48 \mathrm{~mm}$ at point "O.C3" about $20 \mathrm{~mm}$ from the slip plane) were gotten for samples closer to the slip plane while smaller $\mathrm{d}_{50}$ values $(0.45 \mathrm{~mm}$ at point "wet area" about $50 \mathrm{~mm}$ from the slip plane) were obtained further from the slip plane (e.g., Figure 7(c)). This inconsistency in the $\mathrm{d}_{50}$ values with proximity to the slip plane could be due a complex network of anatomizing faults e.g. Figure 3(b). This idea is consistence with the observation reported by [29].

Since grain sorting is another important parameter to measure grain size distribution and determine the rate of wear due to displacement or deformation, the degree of sorting $\left(\mathrm{S}_{\mathrm{o}}\right)$ of the samples were calculated using Equation (2).

$$
\mathrm{S}_{\mathrm{o}}=\sqrt{\mathrm{Q} 3 / \mathrm{Q} 1}
$$

where Q3 and Q1 are the $75^{\text {th }}$ and $25^{\text {th }}$ percentile on the diameter scale. The degree of sorting $\left(\mathrm{S}_{\mathrm{o}}\right)$ varies within shear zones and from one shear zone to the other. For example in SZ III (Figure 7(a)) the $S_{0}$ values varies from e.g., $1.8 \mathrm{~mm}, 1.6 \mathrm{~mm}, 2.2 \mathrm{~mm}$ and $2 \mathrm{~mm}$ for point a, b, c, and d respectively while in SaZS (Figure 7(b)) the 

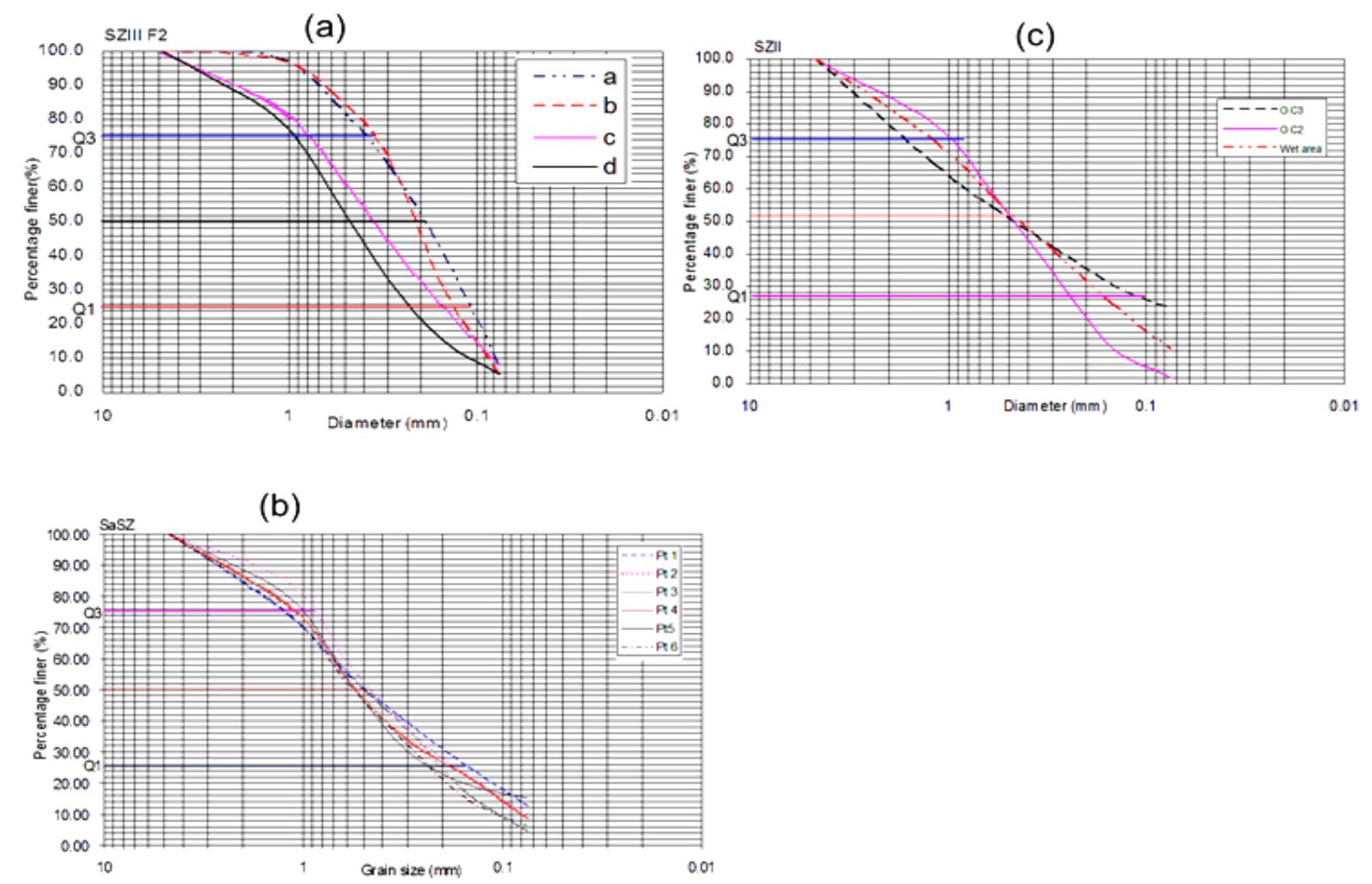

Figure 7. Grain size distribution curves of samples taken from a fault core zone. (a) From SZ III showing increase in $\mathrm{d}_{50}$ value (average grain size) away from the slip plane and vice versa towards the slip plane, See Figure 4(b) for sample point with proximity to the main slip plane; (b) From SaSZ showing the same pattern in grain size distribution as obtained in SZ III, see Figure 5 for sample point with proximity to the main slip plane; (c) From SZ II showing a different pattern in the grain size distributions i.e. larger $\mathrm{d}_{50}$ values obtained in samples close to the slip plane while smaller values in samples away from the slip plane due to a complex network of anastomosing faults, see Figure 3. Q1 and Q3 are the $25^{\text {th }}$ and the $75^{\text {th }}$ percentile respectively on the diameter scale.

values varies from $3 \mathrm{~mm}, 2.3 \mathrm{~mm}, 2.4 \mathrm{~mm}, 2.5 \mathrm{~mm}, 2 \mathrm{~mm}, 2.3 \mathrm{~mm}$ for point 1 to 6 respectively. Because of this variation, a median sorting $\left(\mathrm{M}_{\mathrm{So}}\right)$ value was calculated as follows

$$
\mathrm{M}_{\mathrm{So}}=\sum \mathrm{S}_{\mathrm{o}} / \mathrm{n}
$$

where $\mathrm{n}$ is the number of sampling point.

The results revealed that $\mathrm{M}_{\mathrm{So}}$ range from 2.4 - $3.1 \mathrm{~mm}$ in shear zones within the Atotsugawa fault and from $1.89-2.78 \mathrm{~mm}$ in shear zones within the Ushikubi fault. This implies that the samples range from poorly to very poorly sorted according to the classification of [33]. These observations agree very well with photomicrographs of thin sections of samples collected in proximity to the slip plane (Figures 8-11). The variation in the nature of sorting could be as a result of different rates of displacement within the different shear zones leading to different rates of comminution.

\subsubsection{Microscopic Observations}

The aim of this section is to appreciate how grain texture (grain size and grain shape) varies within and between shear zones with proximity to a slip plane at a microscopic scale. As a result, microphotographs from thin sections revealed that samples very close to the slip plane are finer and the grains shapes range from angular to sub rounded (Figure 8(a) and Figure 8(b)). Figure 8 shows that the fine grains within this zone are embedded in a finer matrix and are rarely in contact with one another. The grain size is fairly to poorly sorted. Coarse grains in this portion are more rounded (Figure 8(a) and Figure 8(b)). Fractures are almost absent in grains within this area.

Figure 9(a) and Figure 9(b) show microphotographs of fault rock collected a few centimeters from the slip 
(a)
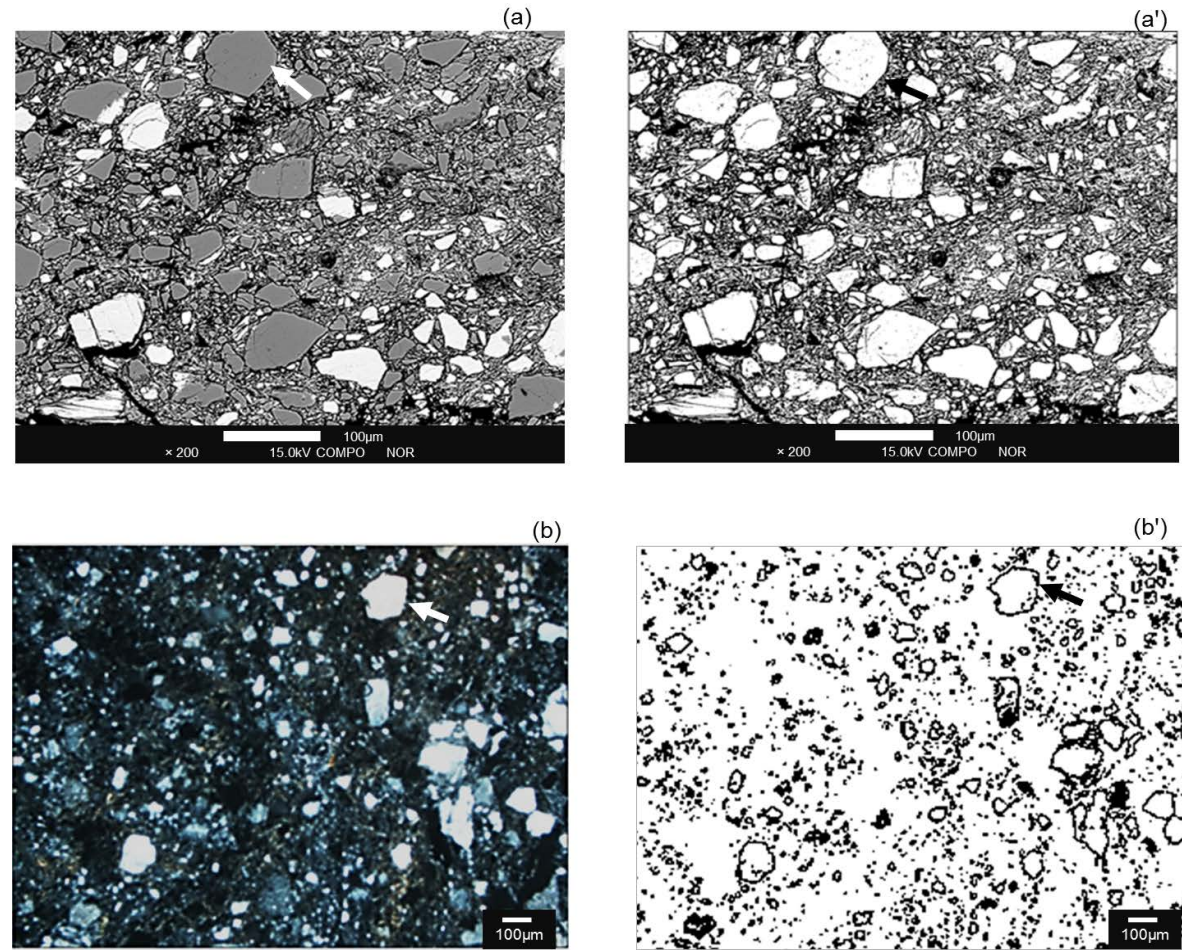

(b)

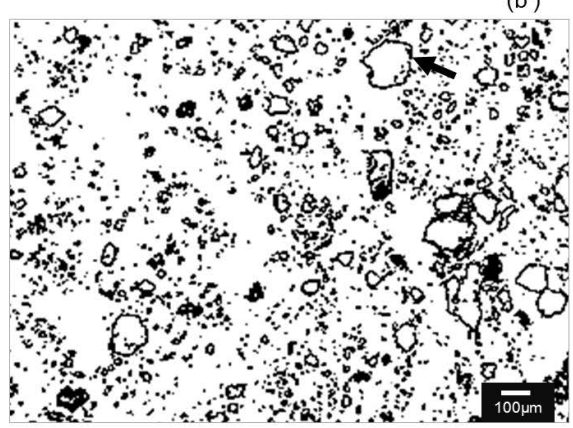

Figure 8. Microphotographs of fault cores from the study site (see the text for explanation). (a) COMP (compositional image); Backscattered contrast, (a') Binary image of (a). (b) Crossed polarized light image (b') Binary image of (b).


Figure 9. Microphotographs of fault cores from the study site (see the text for explanation) (a) COMP (compositional image); Backscattered contrast, (a') Binary image of (a). (b) Crossed polarized light image (b') Binary image of (b). 
plane. In this part the grains are fractured and are partly in contact with one another. The fracturing is such that one part of the grains could still be fitted to the other part preventing the occurrence of fine matrix and the grains show poor sorting.

Further from the slip plane, Figure 10(a) and Figure 10(b) show grains that have been fractured and the fractures filled with calcite (calcite veins). Fractures are evident and cut across the grains but most of the grains are still in contact with one another. The grain size distribution is poorly sorted and most of the coarse grains are elongated and are embedded in a finer matrix (Figure 10(a) and Figure 10(b)).

Figure 11(a) and Figure 11(b) give a general picture of how deformations affect grain shape and size with proximity to a slip plane.

Conclusively, grains in samples close to the slip plane are sub angular to rounded (black and white arrows) Figure 8(a) and Figure 8(b) while those further from the slip plane are sub angular to angular. These results agree with findings of [34] and [35] who reported that increasing roundness is a sign of increasing wear (increasing deformation or displacement). This idea can be confirm in the photomicrographs of Figure 8 and Figure 11 because most of the grains in samples close to the slip plane are sub angular to rounded since large deformation (displacement) is suspected to have taken place whereas those further away are more angular and elongated (e.g., Figure 9 and Figure 11).

\subsection{ESR Spectra}

Since one of the objectives of this study is to investigate how ESR signals intensities vary with proximity to a slip plane, the type and nature of the radiation induced ESR signal (e.g., $\mathrm{E}_{1}^{\prime}$ center in quartz or $\mathrm{C}$ signal in calcite) doesn't not really matter. The most important factor is to see how ESR intensity varies with proximity to a slip plane. Therefore the composition of the fault gouge is not equally a controlling factor to investigate this variation in signal intensity but cannot however be ignored. Some of the ESR spectra were obtained from fault gouge dominant in quartz while others contain calcite and some clay mineral as shown in Figure 12(a) and Figure 12(b). Figure 13 is an example of ESR spectra of fault gouge samples collected from shear zones along the Ushikubi fault and the Atotsugawa fault. Some samples showed only one peak of radiation induced signals
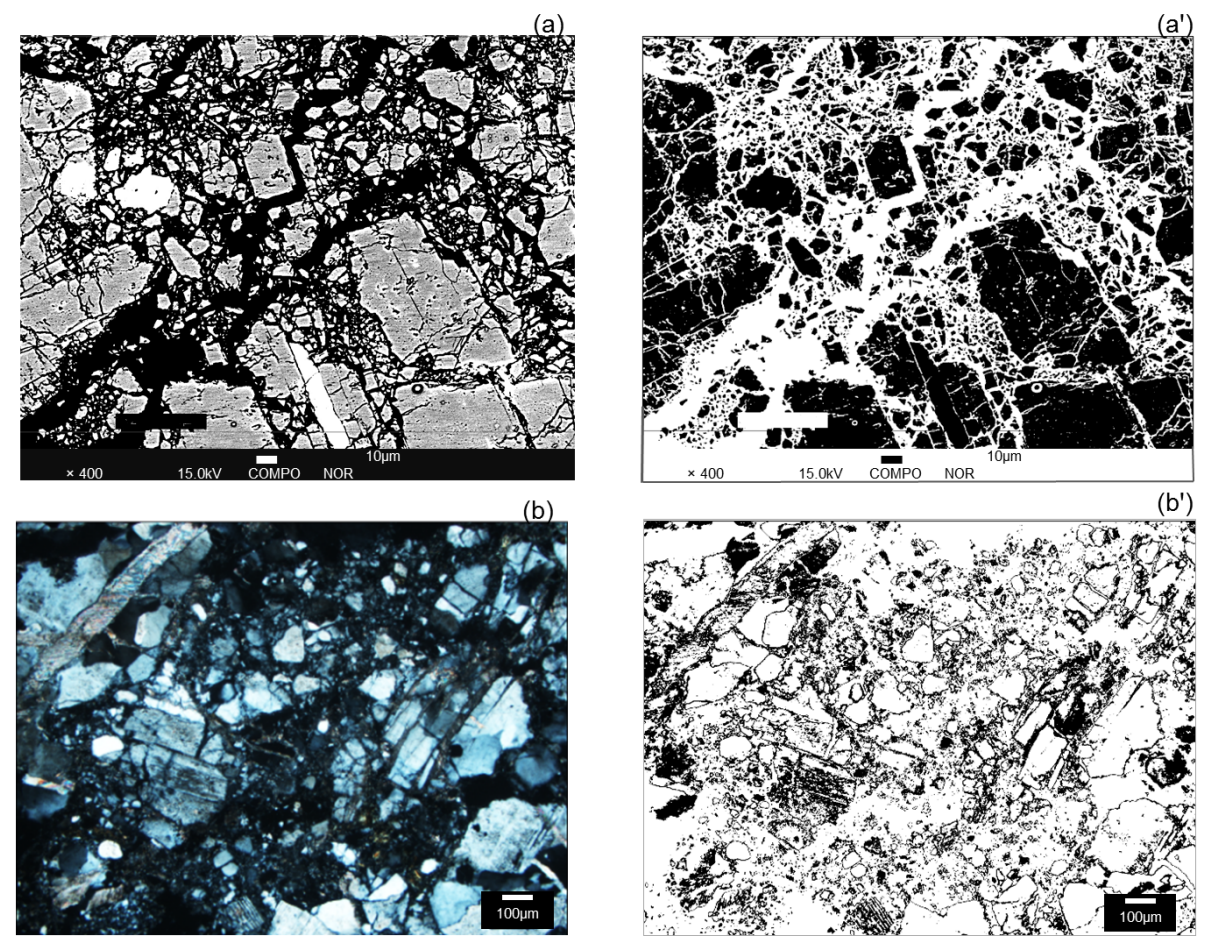

Figure 10. Microphotographs of fault cores from the study site (see the text for explanation). (a) COMP (compositional image); Backscattered contrast, (a') Binary image of (a). (b) Crossed polarized light image (b') Binary image of (b). 


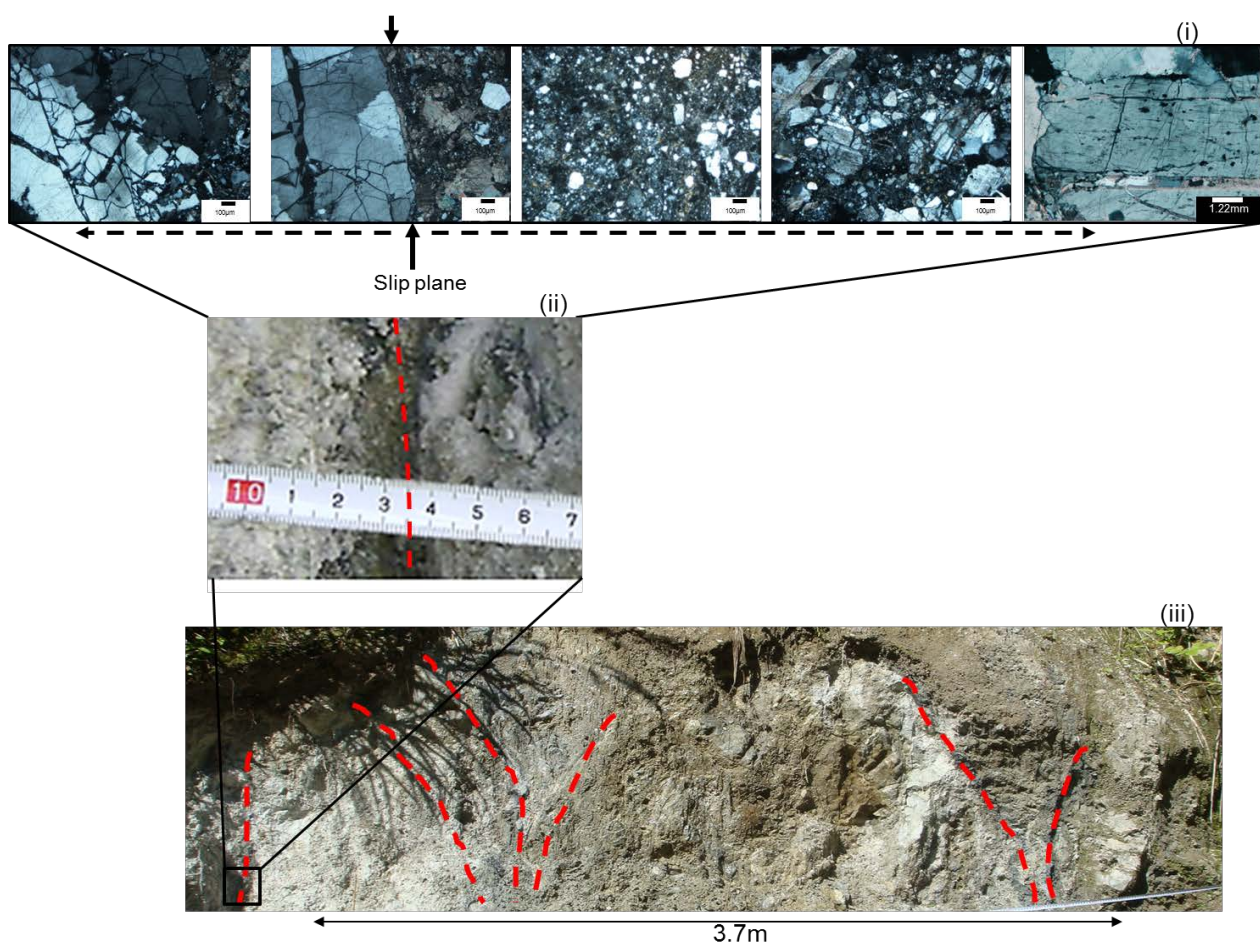

(a)
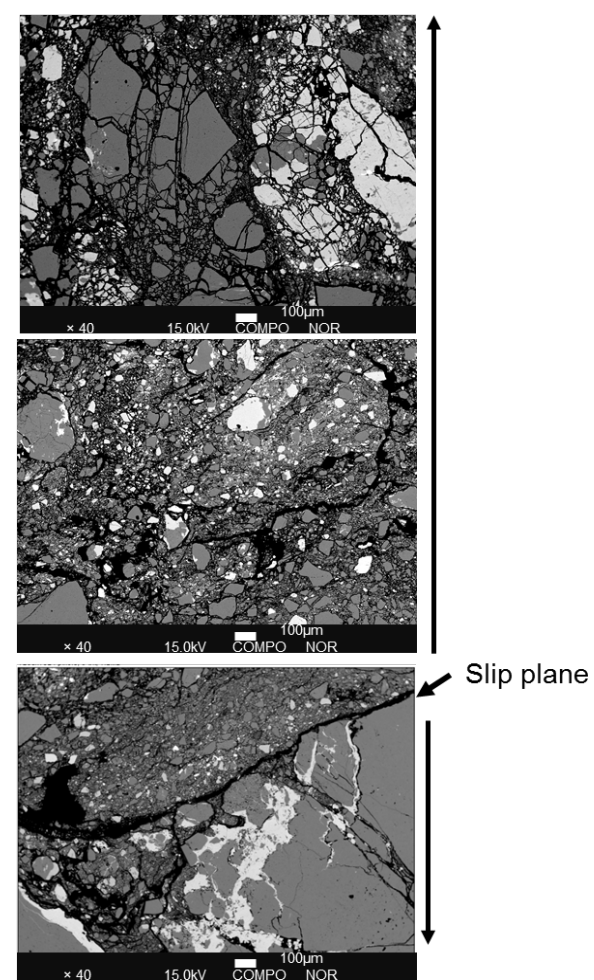

(b)

Figure 11. (a) (i) Combined microphotographs (crossed polarized light) of fault core rocks showing how deformations affect grain shape and size with proximity to a slip plane. Black dotted arrows show increasing distance away from slip plane. (ii) An enlarge part within the fault core zone. (iii) SZ II (see Figure 3); (b) Combined compositional image (backscattered contrast) of fault core rocks equally showing deformation rate with proximity to a slip plane. Vertical black arrows show increasing distance from slip plane. 
(a)
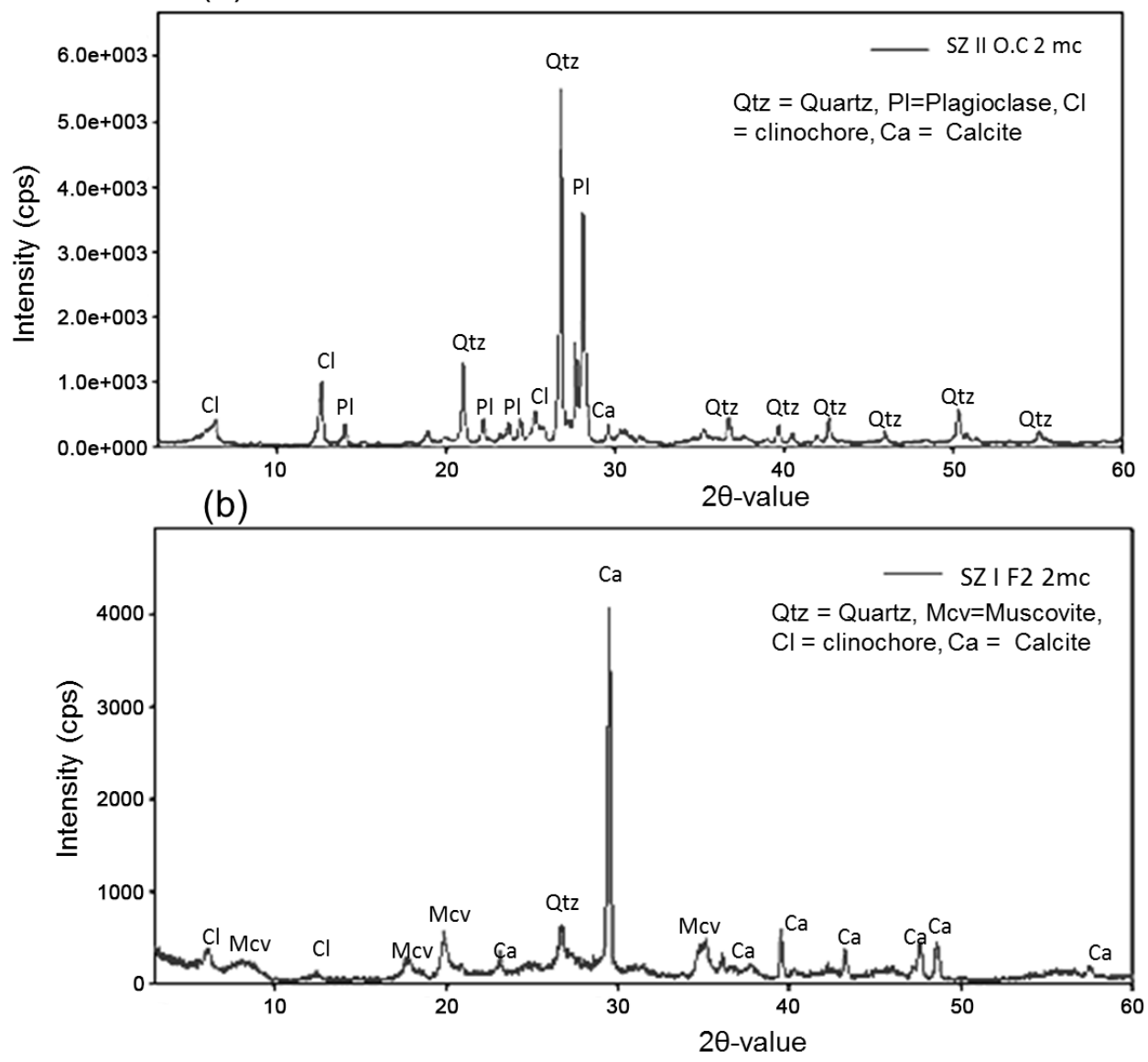

Figure 12. X-ray diffraction pattern obtained from fault core rocks. (a) Sample dominant in quartz with some clay minerals and (b) sample dominant in calcite with some clay minerals. Target: $\mathrm{Cu}$, voltage: $30 \mathrm{Kv}$, Current: $15 \mathrm{~mA}$, Scan speed $4.000^{\circ} / \mathrm{min}$, angle: $3^{\circ}-60^{\circ}$.

(Figure 13(a)) while others showed three peaks (Figure 13(b) and Figure 13(c)). Irrespective of the composition of the fault gouge and the shape of the spectra, the ESR signal intensity of samples from some of the shear zone showed an increasing tendency away from the slip plane (Figure 14(a) and Figure 14(b)) while others did not show such trend (Figure 14(c)).

\section{Discussion}

\subsection{Variation in the Intensity of ESR Signals with Distance from a Slip Plane}

ESR spectra in some of the shear zone revealed that the intensity of the radiation induced ESR signals decreased in samples close to the slip plane and increased away from the slip plane (Figure 14). This observation is consisted with the findings of [20] [32] [36]-[38]. [38] reported that at $0 \mathrm{~mm}$ from the slip plane, frictional heating could cause the reduction in signal intensity of defect centers in quartz grains. Although frictional heating was not investigated in this study, it could not be completely rolled out as a reason for our observation. [39]-[41] also pointed out that defect centers in quartz grains can be reduced to a remarkable extend by shear fracturing at a displacement of more than about $50 \mathrm{~cm}$. Therefore large displacement will lead to decrease in ESR signal intensity. To verify this aspect, displacement in this study was estimated based on the thickness of fault gouge using the functional relationship of Equation (4) developed by [10].

$$
\text { Ds }=8 \mathrm{t}
$$

where, Ds $(\mathrm{cm})$ is the shear displacement and $\mathrm{t}(\mathrm{cm})$ is the mean thickness of the gouge zone. The thickness of 


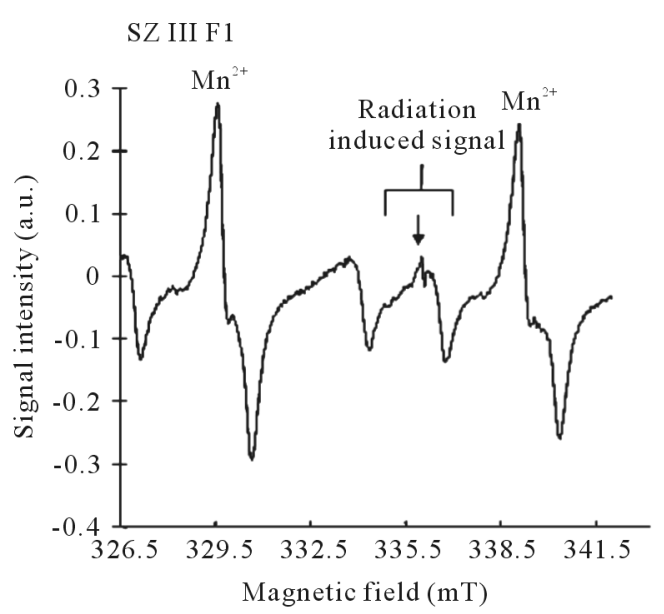

(a)

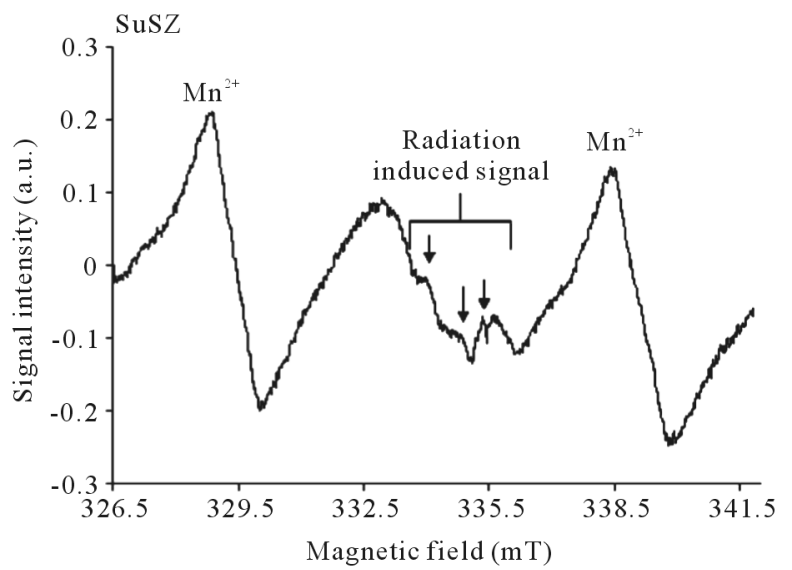

(b)

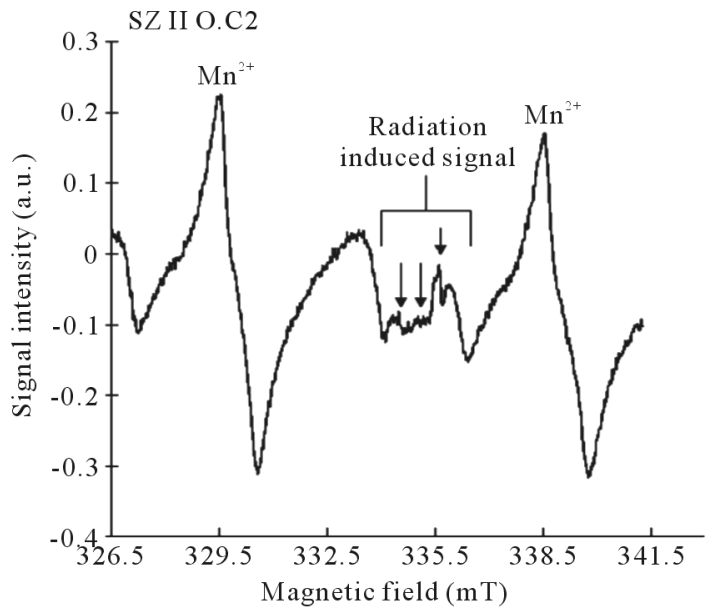

(c)

Figure 13. (a) ESR spectrum of fault core rock showing only one radiation induced peak between the $3^{\text {rd }}$ and the $4^{\text {th }}$ peak of $\mathrm{Mn}^{2+}$ (b) and (c) are ESR spectra showing three induced radiation peak between the $3^{\text {rd }}$ and the $4^{\text {th }}$ peak of $\mathrm{Mn}^{2+}$.

gouge is assumed to increase incrementally during sliding events [19]. However, direct measurement of the gouge thickness within shear zones can nearly be impossible due to shear fracture bifurcation [10], thus the thickness of the gouge zone in this study is assumed to be the thickness of the entire fault core zone. By using the above relationship, a $64 \mathrm{~cm}$ thick gouge zone in the SaSZ (Atotsugawa fault) and a $400 \mathrm{~cm}$ thick gouge zone in SZ I (Ushikubi fault) suggests about $512 \mathrm{~cm}$ and $3200 \mathrm{~cm}$ displacements respectively. This observation supports the hypothesis that when the displacement is $1 \mathrm{~m}$, the intensity of defect centers could be decreased to a zero level [42].

\subsection{Relationship between Grain Size Distribution and ESR Signal Intensity in Samples Taken in Proximity to a Slip Plane}

ESR signal intensities measured in relatively fine grain samples showed a decreasing trend as oppose to coarse grain samples taken further from the slip plane. This trend in signal intensity has equally been observed in experimentally sheared samples e.g., [22] [39] [40] [43] and in natural samples e.g., [36] [38] [43]-[45]. This decrease in signal intensity in fine grained samples close to the slip plane could be attributed to two controlling factors; rate of displacement or deformation and the concentration of defect centers in the fine grain samples. Previous studies have showed that with increasing rate of displacement (deformation), gouge (fine grained) zones grows by incorporating the adjacent breccia zones [8]-[10] [46], implying that an increase in displacement as shown in the previous section will increase comminutation which will reduce the grain size of the samples 


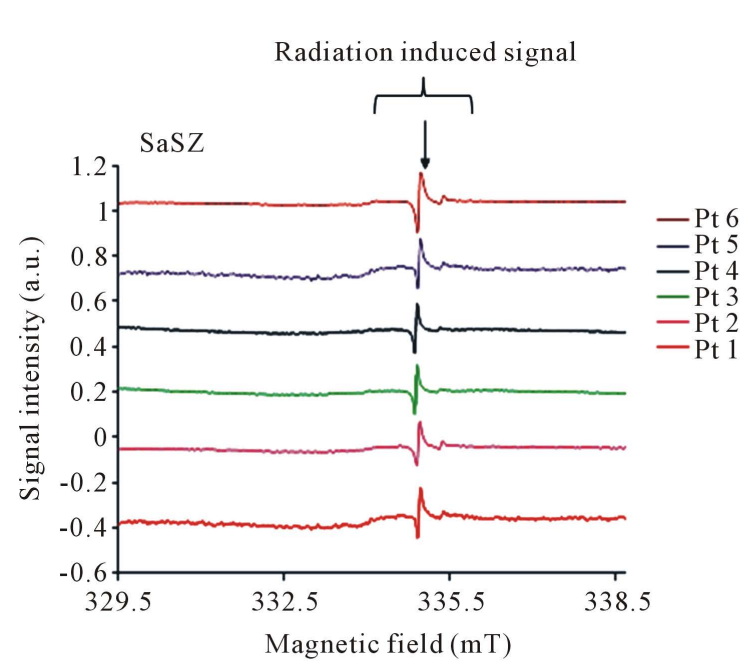

(a)
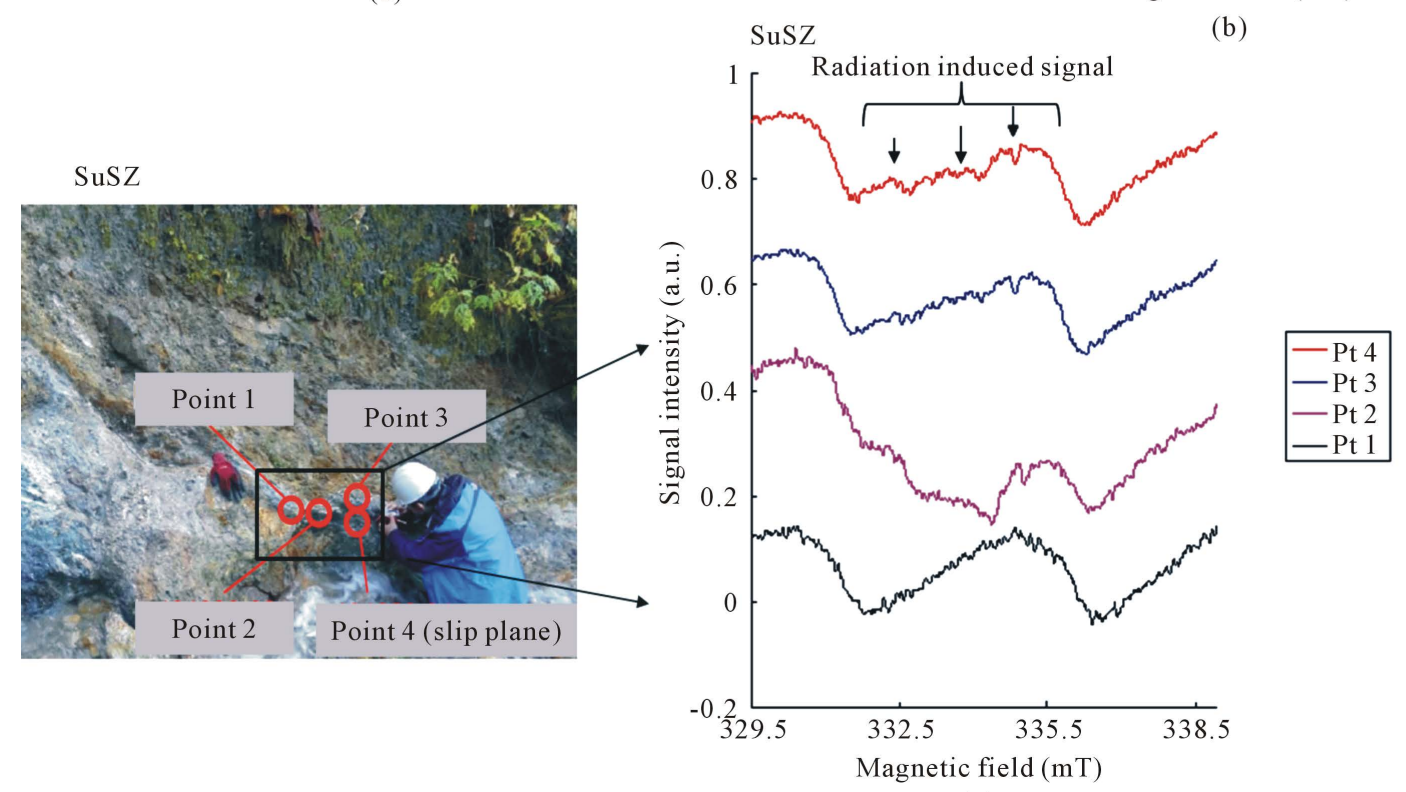

(c)

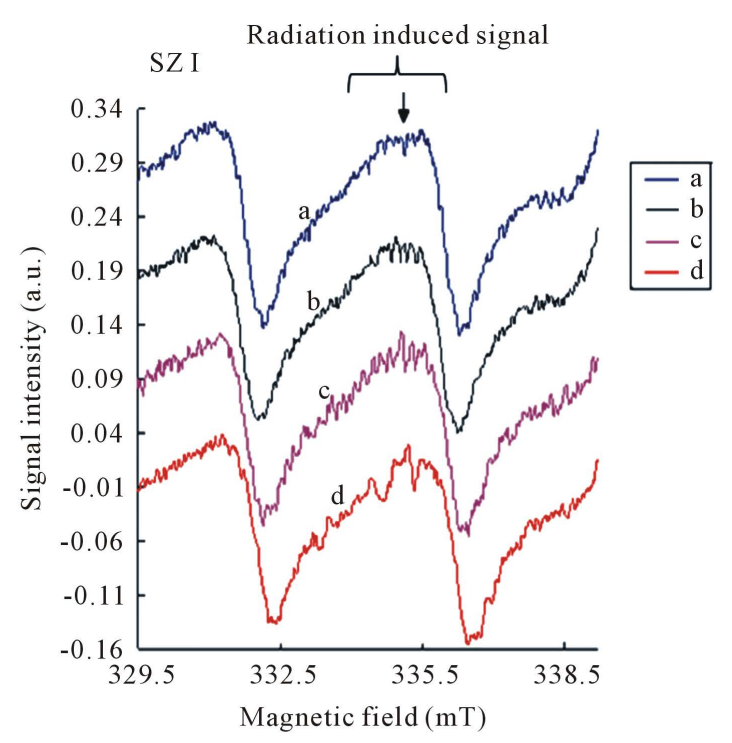

Figure 14. ESR spectra showing variation in the intensity of signal with proximity to the slip plane. (a) and (b) show an increase in the intensity of the radiation induced signal away from the slip plane and decrease in intensity close to the slip plane, see (b) and Figure 5 for sample point; (c) shows an inconsistency in the pattern of signal intensity with proximity to the slip plane. ESR spectrum from point 2 which is supposed to be on the slip plane has a relatively higher intensity than in point 3 which is not directly on the slip plane.

[14]. Figure 15 illustrates the relationship between grain size and signal intensity as a function of distance from a slip plane. Figure 15(a) and Figure 15(b) showed that grain size and signal intensities increase with increasing distance from the slip plane. However, this trend was not respected in all the shear zones in that the ESR intensities of some of the samples close to the slip instead increased likewise the grain size. The reverse trend in the intensity of ESR signals have equally been observed by [21] [40] [43] [47]-[49]. This inconsistency in the pattern of grain size distribution and signal intensity could be as a result of the anatomizing network of faults in SZ II (Ushikubi fault) and SuSZ (Atotsugawa fault) leading to the admixture of fault rock from different faulting events with different magnitude.

With respect to the concentration of defect centers, in relatively fine grained samples the concentration of the defect center is expected to reduce due to the small surface area that is exposed. In ESR analysis, signal intensity 

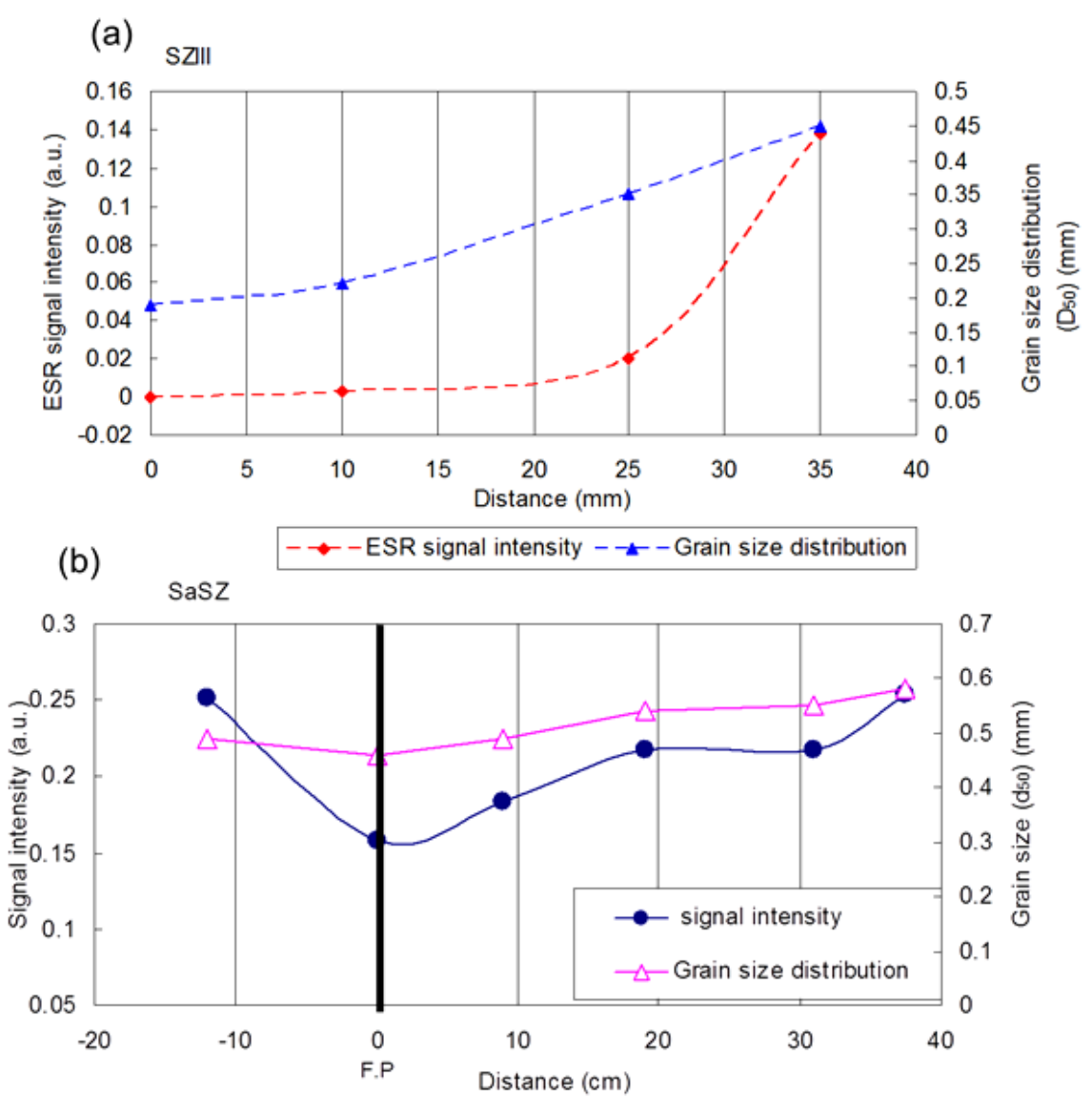

Figure 15. Graph showing the relationship between ESR signal intensity and grain size distribution. The intensity of the ESR signal increase with proximity to the slip plane. The $d_{50}$ values in both (a) and (b) obtained from samples taken with proximity to the slip plane, becomes coarser away from the fault plane (F.P) or slip plane.

is proportional to the defect concentration [32]. Large grains will have higher concentrations of defects than finer grains which lead to an increase in signal intensity. In this study, an increase in signal intensity was observed in samples further from the slip plane that have suffered little or no deformation (displacement). This observation is consistent with that of [42] in that signal intensity decrease with decreasing grain size because the relative amount of defect centers in the samples decreases with the grain size. However, [47] pointed out that, new surface creation accompanying shear fracture can also increase the quantity of defects and consequently produce increased in signal intensities, which could be another reason for an increase in signal intensity that was observed in some of the samples.

\section{Some limitations of This Study}

\subsection{Sieve Method}

Because of the pulverized nature of fault core rocks, loss of particles during sieving is an inevitable process no matter the caution taken. Although that factor was ignored, it could affect the grain size distribution curves. Since there are a lot of difficulties often involved in collecting samples within a narrow range in a fault core zone, the weight of the samples used in this study may not be the representative of the entire shear zone thus highlighting the need for further investigation in the near future.

\subsection{Estimation of the Displacement}

Some of the drawback in the estimation of the displacement is that the actual thickness of gouge within the 
gouge zone in the portion where the samples were collected was not measured, rather a general thickness of the gouge zone was considered.

\section{Conclusions}

Grain size distribution analysis revealed that samples with larger $\mathrm{d}_{50}$ values are dominant in sites located further from the slip plane while those with smaller $d_{50}$ values are close to the slip plane. However an inconsistency in this order was observed in some of the shear zones due to admixture of fault gouges from different fault activities.

Microphotographs showed that the grains in samples close to the slip plane are finer, sub-rounded to rounded and rarely in contact with one another due to intensive crushing indicating increasing wear leading to large displacement. Further from the slip plane, the grains are coarser, more elongated and are almost in contact with each other.

The intensity of ESR signal reduces in samples close to the slip plane in most of the shear zone. However, this tendency was not same in all the shear zones due to a complex network of anatomizing faults in some of the shear zones.

The idea that grain size distribution varies within shear zones indicates that, more than one faulting events have taken place in the past thus underscoring the need for further investigation of the possibility of reoccurrence of faults.

\section{Acknowledgements}

This work is part of an ongoing Ph.D. program and the authors sincerely acknowledge the support from MEXT for providing logistics during my stay in Japan within the framework of Monbushokagaku scholarship. Special thanks go to Prof. Yasuo Ishizaki for allowing us to use the super probe JEOL JXA-8230T Electron probe microanalyzer in the University of Toyama, Japan. We are equally indebted to Prof. Shigeru Otoh for allowing us to use their OPTIPHOT 2-POL optical microscope and also to Prof. Masaaki Shimizu for the use of X-ray diffractometer. We are grateful to Dr. Fantong Wilson Yetoh for critical comments during the preparation of this manuscript. Sincere thanks also go to the anonymous reviewers for reviewing this manuscript. Their critical comments and suggestions improved the quality of this manuscript.

\section{References}

[1] Sibson, R.H. (2003) Thickness of the Seismic Slip Zone. Bulletin of the Seismological Society of America, 93, 11691178. http://dx.doi.org/10.1785/0120020061

[2] Chester, F.M., Evans, J.P. and Biegl, R.L. (1993) Internal Structure and Weakening Mechanisms of the San-Andreas Fault. Journal of Geophysical Research-Solid Earth, 98, 771-786. http://dx.doi.org/10.1029/92JB01866

[3] Kim, Y.S., Peacock, D.C.P. and Sanderson, D.J. (2004) Fault Damage Zones. Journal of Structural Geology, 26, 503517. http://dx.doi.org/10.1016/j.jsg.2003.08.002

[4] Caine, J.S., Evans, J.P. and Forster, C.B. (1996) Fault Zone Architecture and Permeability Structure. Geology, 24, 1025-1028. http://dx.doi.org/10.1130/0091-7613(1996)024<1025:FZAAPS > 2.3.CO;2

[5] Bruhn, R.L., Parry, W.T., Yonkee, W.A. and Thompson, T. (1994) Fracturing and Hydrothermal Alteration in Normal Fault Zones. Pure and Applied Geophysics, 142, 609-644. http://dx.doi.org/10.1007/BF00876057

[6] Passchie, R.C.W. and Trouw, R.A.J. (1996) Microtectonics. Springer-Verlag, Berlin.

[7] Fondriest, M., Smith, S.A.F., Toro, G.D., Zampieri, D. and Mittempergher, S. (2012) Fault Zone Structure and Seismic Slip Localization in Dolostone, an Example from the South Alps, Italy. Journal of structural Geology, 45, 52-67. http://dx.doi.org/10.1016/j.jsg.2012.06.014

[8] Scholz, C.H. (2002) The Mechanics of Earthquakes and Faulting. Cambridge University Press, Cambridge. http://dx.doi.org/10.1017/CBO9780511818516

[9] Billi, A. (2005) Grain Size Distribution and Thickness of Breccia and Gouge Zones from Thin ( $<1$ m) Strike-Slip Fault Cores in Limestone. Journal of Structural Geology, 27, 1823-1837.

[10] Engelder, T. (1974) Cataclasis and the Generation of Fault Gouge. Geological Society of America Bulletin, 85, 15151522. http://dx.doi.org/10.1130/0016-7606(1974)85<1515:CATGOF>2.0.CO;2

[11] Laws, S., Eberhardt, E., Loew, S. and Descoeudres, F. (2003) Geomechanical Properties of Shear Zones in the Eastern 
Aar Massif, Switzerland and Their Implication on Tunnelling. Rock Mechanics and Rock Engineering, 36, 271-303. http://dx.doi.org/10.1007/s00603-003-0050-8

[12] Sibson, R. (1977) Fault Rocks and Fault Mechanisms. Journal of the Geological Society, 133, 191-213. http://dx.doi.org/10.1144/gsigs.133.3.0191

[13] Matin, A., Banerjee, S., Gupta, C.D. and Banerjee, N. (2012) Progressive Deformation across a Ductile Shear Zone: An Example from the Singhbhum Shear Zone, Eastern India. International Geology Review, 54, 290-301. http://dx.doi.org/10.1080/00206814.2010.543781

[14] Sammis, C., King, G. and Biegel, R. (1987) The Kinematics of Gouge Deformation. Pure and Applied Geophysics, 125, 777-812. http://dx.doi.org/10.1007/BF00878033

[15] Tanaka, H., Fujimoto, K., Ohtani, T. and Ito, H. (2001) Structural and Chemical Characterization of Shear Zones in the Freshly Activated Nojima Fault, Awaji Island, Southwest Japan. Journal of Geophysical Research, 106, 8789-8810. http://dx.doi.org/10.1029/2000JB900444

[16] Wilson, J., Chester, J. and Chester, F. (2003) Microfracture Analysis of Fault Growth and Wear Processes, Punchbowl Fault, San Andreas System, California. Journal of Structural Geology, 25, 1855-1873. http://dx.doi.org/10.1016/S0191-8141(03)00036-1

[17] Buhay, W.M., Schwarcz, H.P. and Grun, R. (1988) ESR Dating of Fault Gouge: The Effect of Grain Size. Quaternary Science Reviews, 7, 515-522. http://dx.doi.org/10.1016/0277-3791(88)90055-8

[18] Fukuchi, T. (1989) Theoretical Study on Frictional Heat by Faulting Using Electron Spin Resonance. International Journal of Radiation Applications and Instrumentation. Part A. Applied Radiation and Isotopes, 40, 1181-1193. http://dx.doi.org/10.1016/0883-2889(89)90061-0

[19] Gundu Rao, T.K., Rajendran, C.P., Mathew, G. and John, B. (2002) Electron Spin Resonance Dating of Fault Gouge from Desamangalam, Kerala: Evidence for Quaternary Movement in Palghat Gap Shear Zone. Proceedings of the Indian Academy of Sciences-Earth and Planetary Sciences, 111, 103-113.

[20] Ikeya, M., Miki, T. and Tanaka, K. (1982) Dating of a Fault by ESR on Intrafault Materials. Science, 215, 1391-1393. http://dx.doi.org/10.1126/science.215.4538.1392

[21] Lee, H.K. and Schwarcz, E.P. (1993) An Experimental Study of Shear-Induced Zeroing of ESR Signals in Quartz. Applied Radiation and Isotopes, 44, 191-195. http://dx.doi.org/10.1016/0969-8043(93)90218-Y

[22] Miki, T. and Ikeya, M. (1982) Physical Basis of a Fault Dating with ESR. Naturwissenschaften, 69, 390-391. http://dx.doi.org/10.1007/BF00396692

[23] Amitrano, D. and Schmittbuhl, J. (2002) Fracture Roughness and Gouge Distribution of a Granite Shear Band. Journal of Geophysical Research, 107, ESE 19-1-ESE 19-16. http://dx.doi.org/10.1029/2002JB001761

[24] Aydin, A. (1978) Small Faults Formed as Deformation Bands in Sandstone. Pure and Applied Geophysics, 116, 913930. http://dx.doi.org/10.1007/BF00876546

[25] LeB. Hooke, R. and Iverson, N.R. (1995) Grain-Size Distribution in Deforming Subglacial Tills: Role of Grain Fracture. Geology, 23, 57-60. http://dx.doi.org/10.1130/0091-7613(1995)023<0057:GSDIDS>2.3.CO;2

[26] Mandl, G., De Jong, L.N.J. and Maltha, A. (1977) Shear Zones in Granular Material-An Experimental Study of Their Structure and Mechanical Genesis. Rock Mechanics, 9, 95-144. http://dx.doi.org/10.1007/BF01237876

[27] Fukuchi, T., Mie, H., Okubo, S. and Imai, N. (2002) Assessment of Fault Activity by ESR Dating of Fault Gouge Using Surface E' Center in Quartz Produced with Clay Mineralization: The Case of the Atotsugawa Fault in Japan. Advances in ESR Applications, 18, 145-151.

[28] Fantong, E.B., Takeuchi, A. and Doke, R. (2013) Electron Spin Resonance (ESR) Dating of Calcareous Fault Gouge of the Ushikubi Fault, Central Japan. Applied Magnetic Resonance, 44, 1105-1123. http://dx.doi.org/10.1007/s00723-013-0471-9

[29] Oohashi, K. and Kobayashi, K. (2008) Fault Geometry and Paleo-Movement of the Central Part of the Ushikubi Fault, Northern Central Japan. Journal of the Geological Society of Japan, 114, 16-30. (In Japanese with English Abstract) http://dx.doi.org/10.5575/geosoc.114.16

[30] Takeuchi, A., Takebe, A., Ongirad, H. and Doke, R. (2007) Seismology of the Atotsugawa Strike-Slip Fault in the Hida Mountains, Central Japan with the Special Reference to the Investigation Gallery across the Branch Mozumi-Sukenobe Fault. In: Geodynamics of Atotsugawa Fault System, Terrapub, Tokyo, 1-10.

[31] Research Group of Active Fault of Japan (1991) Active Faults in Japan; Sheet Maps and Inventories (Revised Edition). University of Tokyo Press, Tokyo, 437. (In Japanese with English Abstracts)

[32] Ikeya, M. (1993) New Applications of Electron Spin Resonance. Dating, Dosimetry and Microscopy. World Scientific, Singapore. 
[33] Blott, S.J. and Pye, K. (2001) Gradistat: A Grain Size Distribution and Statistics Package for the Analysis of Unconsolidated Sediments. Earth Surface Processes and Landforms, 26, 1237-1248. http://dx.doi.org/10.1002/esp.261

[34] Cladouhos, T.T. (1999) Shape Preferred Orientations of Survivor Grains in Fault Gouge. Journal of Structural Geology, 21, 419-436. http://dx.doi.org/10.1016/S0191-8141(98)00123-0

[35] Storti, F., Billi, A. and Salvini, F. (2003) Particle Size Distributions in Natural Carbonate Fault Rocks: Insights for Non-Self-Similar Cataclasis. Earth and Planetary Science Letters, 206, 173-186. http://dx.doi.org/10.1016/S0012-821X(02)01077-4

[36] Fukuchi, T. (2001) Assessment of Fault Activity by ESR Dating of Fault Gouge; an Example of the $500 \mathrm{~m}$ Core Samples Drilled into the Nojima Earthquake Fault in Japan. Quaternary Science Reviews, 20, 1005-1008. http://dx.doi.org/10.1016/S0277-3791(00)00064-0

[37] Fukuchi, T. and Imai, N. (1998) Resetting Experiment of E' Centres by Natural Faulting-The Case of the Nojima Earthquake Fault in Japan. Quaternary Geochronology, 17, 1063-1068.

[38] Fukuchi, T. and Imai, N. (2001) ESR and ICP Analyses of the DPRI 500 m Drill Core Samples Penetrating through the Nojima Fault, Japan. Island Arc, 10, 465-478.

[39] Ariyama, T. (1985) Conditions of Resetting the ESR Clock during Faulting. In: Ikeya, M. and Miki, T., Eds., ESR Dating and Dosimetry, IONICS, Tokyo, 249-256.

[40] Tanaka, K. and Shidahara, T. (1985) Fracturing, Crushing and Grinding Effects of ESR Signal of Quartz. In: Ikeya, M. and Miki, T., Eds., ESR Dating and Dosimetry, IONICS, Tokyo, 239-247.

[41] Tanaka, K. (1985) Experimental Study on Annealing of ESR Signal of Quartz during Faulting. In: Ariyama, T., Ed., Conditions of Resetting the ESR Clock during Faulting, IONICS, Tokyo, 249-256.

[42] Fukuchi, T. (1991) The Itoigawa-Shizuoka Tectonic Line at the Western Edge of the South Fossa Magna. Japan. Mod. Geology, 15, 347-366

[43] Fukuchi, T. and Imai, N. (1998) ESR Isochron Dating of the Nojima Fault Gouge, Southwest Japan, Using ICP-MS: An Approach to Fluid Flow Events in the Fault Zone. Geological Society, London Special Publications, 144, $261-277$. http://dx.doi.org/10.1144/GSL.SP.1998.144.01.19

[44] Toyoda, S., Rink, W.J., Schwarz, H.P. and Rees-Jones, J. (2000) Crushing Effects on TL and OSL on Quartz: Relevance to Fault Dating. Radiation Measurements, 32, 667-672. http://dx.doi.org/10.1016/S1350-4487(00)00088-3

[45] Hattori, I. and Yamamoto, H. (1999) Rock Fragmentation and Particle Size in Crushed Zones by Faulting. Journal of Geology, 107, 209-222. http://dx.doi.org/10.1086/314343

[46] Matsumoto, H., Yamanaka, C. and Ikeya, M. (2001) ESR Analysis of the Nojima Fault Gouge, Japan, from the DPRI $500 \mathrm{~m}$ Borehole. The Island Arc, 10, 479-485. http://dx.doi.org/10.1046/j.1440-1738.2001.00346.x

[47] Keulen, N., Heilbronner, R., Stünitz, H., Boullier, A. and Ito, H. (2007) Grain Size Distributions of Fault Rocks: A Comparison between Experimentally and Naturally Deformed Granitoids. Journal of Structural Geology, 29, 12821300. http://dx.doi.org/10.1016/j.jsg.2007.04.003

[48] Hiraga, S., Morimoto, A. and Shimamoto, T. (2002) Stress Effect on Thermoluminescence Intensities of Quartz Grains-For the Establishment of a Fault Dating Method. Bulletin of Nara University of Education, 51, 17-24.

[49] Toyoda, S. and Schwarcz, H.P. (1996) The Spatial Distribution of ESR Signals in Fault Gouge Revealed by Abrading Technique. Applied Radiation and Isotopes, 47, 1409-1413. 
Scientific Research Publishing (SCIRP) is one of the largest Open Access journal publishers. It is currently publishing more than 200 open access, online, peer-reviewed journals covering a wide range of academic disciplines. SCIRP serves the worldwide academic communities and contributes to the progress and application of science with its publication.

Other selected journals from SCIRP are listed as below. Submit your manuscript to us via either submit@scirp.org or Online Submission Portal.
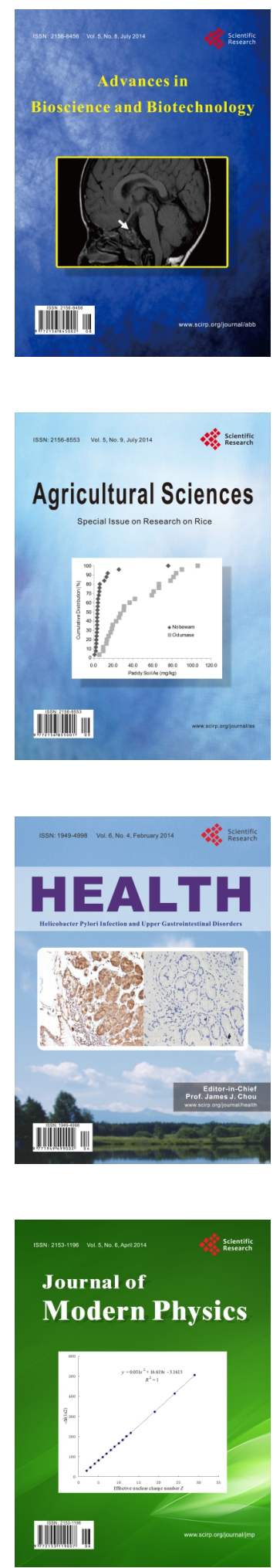
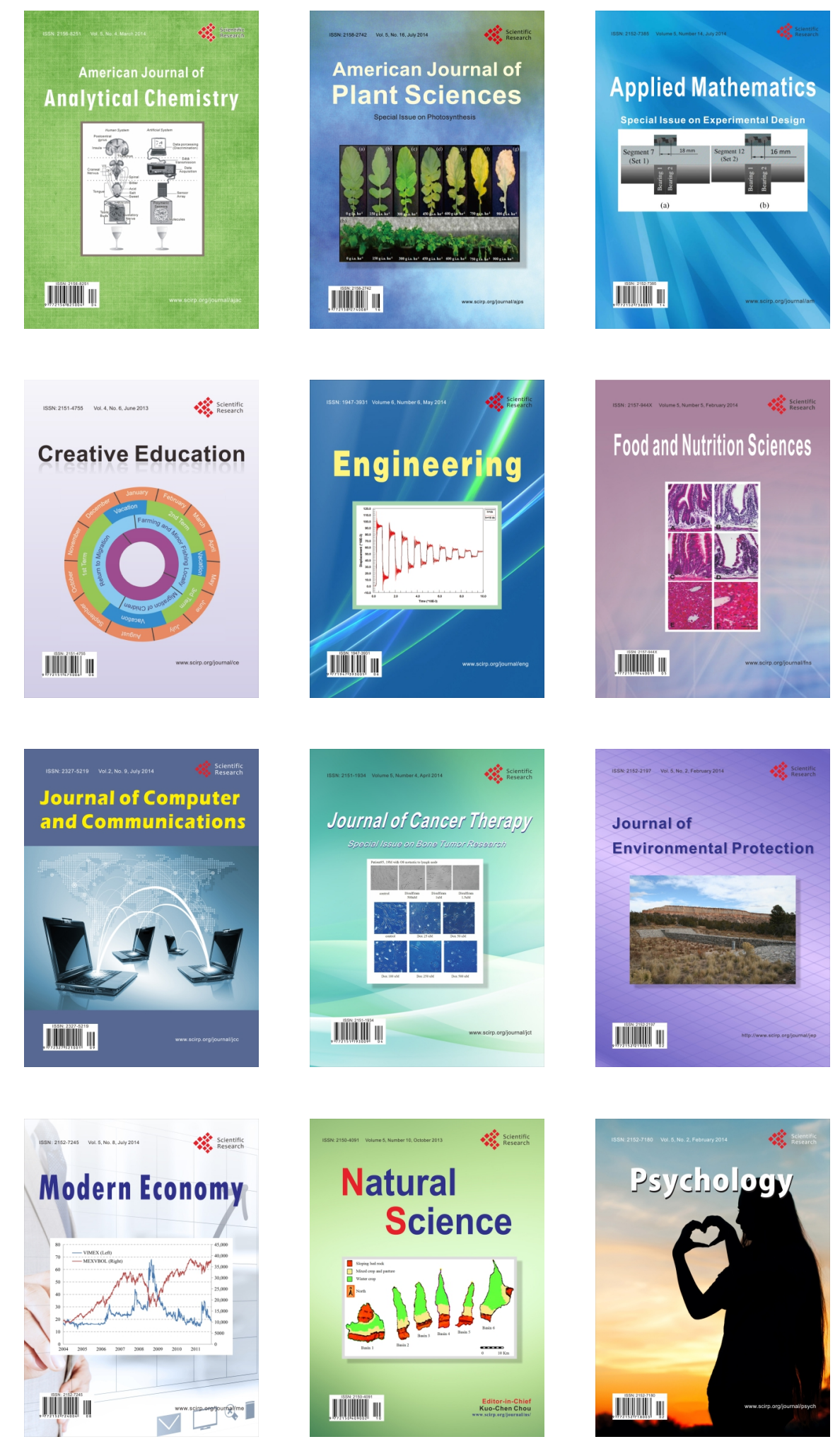